\title{
Aerobic and anaerobic reduction of birnessite by a novel Dietzia strain
}

\author{
Huiqin Zhang ${ }^{1 \dagger}$, Yan Li ${ }^{1 \dagger}$, Xin Wang ${ }^{1}$, Anhuai Lu ${ }^{1 *}$, Hongrui Ding ${ }^{1}$, Cuiping Zeng ${ }^{1}$, Xiao Wang ${ }^{1}$, Xiaolei Wu², \\ Yong $\mathrm{Nie}^{2}$ and Changqiu Wang ${ }^{1}$
}

\begin{abstract}
Background: Mn oxides occur in a wide variety of geological settings and exert considerable influences on the components and chemical behaviors of sediments and soils. Microbial reduction of $\mathrm{Mn}$ oxides is an important process found in many different environments including marine and freshwater sediments, lakes, anoxic basins, as well as oxicanoxic transition zone of ocean. Although the pathway of Mn anaerobic reduction by two model bacteria, Geobacter and Shewanella, has been intensively studied, Mn bio-reduction is still the least well-explored process in nature. Particularly, reduction of $\mathrm{Mn}$ oxides by other bacteria and in the presence of $\mathrm{O}_{2}$ has been fewly reported in recent publishes.

Results: A series of experiments were conducted to understand the capability of Dietzia DQ12-45-1b in bioreduction of birnessite. In anaerobic systems, Mn reduction rate reached as high as $93 \%$ within 4 weeks when inoculated with $1.0 \times 10^{10} \mathrm{cell} / \mathrm{s} / \mathrm{mL}$ Dietzia DQ12-45-1b strains. Addition of AQDS enhanced Mn reduction rate from 53 to $91 \%$. The anaerobic reduction of $\mathrm{Mn}$ was not coupled by any increase in bacterial protein concentration, and the reduction rate in the stable stage of day $2-14$ was found to be in good proportion to the protein concentration. The anaerobic reduction of birnessite released $\mathrm{Mn}(\mathrm{II})$ either into the medium or adsorbed on the mineral or bacteria surface and resulted in the dissolution of birnessite as indicated by XRD, SEM and XANES. Under aerobic condition, the reduction rate was only $37 \%$ with a cell concentration of $1.0 \times 10^{10} \mathrm{cell} / \mathrm{s} / \mathrm{mL}$, much lower than that in parallel anaerobic treatment. Bacterial growth under aerobic condition was indicated by time-course increase of protein and $\mathrm{pH}$. In contrast to anaerobic experiments, addition of AQDS decreased Mn reduction rate from 25 to $6 \%$. The reduced $\mathrm{Mn}$ (II) combined with carbon dioxide produced by acetate metabolism, as well as an alkaline $\mathrm{pH}$ environment given by cell growth, finally resulted in the formation of $\mathrm{Mn}$ (II)-bearing carbonate (kutnohorite), which was verified by XRD and XANES results. The system with the highest cell concentration of $1.0 \times 10^{10}$ cell $\mathrm{s} / \mathrm{mL}$ gave rise to the most amount of kutnohorite, while concentration of $\mathrm{Mn}$ (II) produced with cell concentration of $6.2 \times 10^{8} \mathrm{cell} / \mathrm{s} / \mathrm{mL}$ was too low to thermodynamically favor the formation of kutnohorite but result in the formation of aragonite instead.
\end{abstract}

Conclusion: Dietzia DQ12-45-1b was able to anaerobically and aerobically reduce birnessite. The rate and extent of $\mathrm{Mn}(\mathrm{IV})$ reduction depend on cell concentration, addition of AQDS or not, and presence of $\mathrm{O}_{2}$ or not. Meanwhile, $\mathrm{Mn}(\mathrm{IV})$ bioreduction extent and suspension conditions determined the insoluble mineral products.

\section{Background}

Manganese is the 10th most abundant element in the Earth's crust and second only to iron as the transition metal with alternating redox states $[1,2]$. More than 30

\footnotetext{
*Correspondence: ahlu@pku.edu.cn

${ }^{+}$Huiqin Zhang and Yan Li contributed equally to this work

${ }^{1}$ The Key Laboratory of Orogenic Belts and Crustal Evolution, School of Earth and Space Sciences, Peking University, Beijing 100871, People's Republic of China

Full list of author information is available at the end of the article
}

kinds of Mn oxide/hydroxide minerals ubiquitously distribute in natural environment [2], which are highly chemically active, and have been recognized as being important in controlling the availability and distribution of many trace metals [2-6]. Mn cycling depends on various environmental conditions, such as $\mathrm{pH}$, Eh and temperature etc., which lead to complicated behaviors of $\mathrm{Mn}$ such as dissolution, precipitation and phase transformation [2, 7-11]. Microbially influenced transformations of $\mathrm{Mn}$ which have been previously reported to take place

\section{Chemistry Central}


in soils, sediments, mine tailings, and marine environments, also play an important role in driving geochemical cyclings of Mn [7-12].

The formation of many naturally occurring Mn oxides is found to be associated with microbial $\mathrm{Mn}$ (II) oxidation processes [3, 4, 13-15]. Meanwhile, microorganisms were also found to participate in $\mathrm{Mn}(\mathrm{IV})$ oxides reduction processes, either by using $\mathrm{Mn}(\mathrm{IV})$ as a sole electron acceptor or excreting organics to reduce $\mathrm{Mn}(\mathrm{IV})$ as a detoxification mechanism [16-18]. Geobacter sp. and Shewanella sp. are two representative species of dissimilatory metal reducing bacteria (DMRB) and have been extensively investigated with respect to their ability to reduce $M n(I V)[10,16$, 19-22]. Reduction of Mn(IV) oxides by other DMRB have been seldom reported in recent publishes.

Recent researches carried out the dissimilatory Mn(IV) reduction under anoxic conditions. In the absence of oxygen, some manganese-reducing organisms may use manganese oxides as electron acceptors [16, 17]. While some laboratory studies observed that the presence of oxygen did not inhibit microbial manganese reduction due to the existence of a manganese-reductase system whose activity was inducible by $\mathrm{Mn}(\mathrm{II})$ and unaffected by $\mathrm{O}_{2}[23,24]$. Although Mn(IV) reduction has been more commonly observed in anaerobic conditions, it may also occur in the presence of oxygen.

Factually, biotic manganese reduction is complicated in natural environments and is found to be influenced by various factors. Besides the types of microbial species and $\mathrm{O}_{2}$ level, electron shuttles, such as humic acid and quinone-containing compounds, also have great influences on microbial $\mathrm{Mn}(\mathrm{IV})$ reduction rates $[18,25,26]$. Lovley [25] proved that addition of humic substances or anthraquinone-2,6-disulfonate (AQDS) greatly stimulated the reduction activity of Geobacter metallireducens. Ruebush [26] testified that enzymatic reduction of Mn oxides by membrane fractions from Shewanella oneidensis MR-1 was accelerated with addition of AQDS.

In this study, a fermentative facultative anaerobe, Dietzia strain DQ12-45-1b, which was isolated from a microaerobic condition, was investigated for reduction of a most common $\mathrm{Mn}(\mathrm{IV})$ oxide, birnessite. Given previously reported observations, microbial $\mathrm{Mn}$ (IV) reduction by DQ12-45-1b were further studied by examining possible constrains of cell densities, $\mathrm{O}_{2}$ and electron shuttles (AQDS) on Mn(IV) reduction rates as well as the resulting Mn-bearing mineral products.

\section{Methods}

\section{Birnessite preparation}

Birnessite was synthesized using the method described by McKenzie [27]. A $30 \mathrm{~mL}$ concentrated $\mathrm{HCl}$ (AR) was added dropwisely with stirring to a boiling solution containing $0.2 \mathrm{~mol} \mathrm{KMnO}_{4}(\mathrm{AR})$ dissolved in $350-400 \mathrm{~mL}$ of water. After all $30 \mathrm{~mL} \mathrm{HCl}$ added into the $\mathrm{KMnO}_{4}$ solution, the reaction was continued under another $30 \mathrm{~min}$ boiling. The precipitate was filtered and washed 15 times with deionized water [18 M $\Omega$ conductivity (Reference, Merck Milipore, Germany)] to remove $\mathrm{K}^{+}$and $\mathrm{Cl}^{-}$possibly adsorbed on the mineral surface. The resulting precipitate was dried in air at $45^{\circ} \mathrm{C}$ over night and then stored for further test and experiment.

\section{Bacteria}

Dietzia strain DQ12-45-1b was isolated from oil production water in a deep subterranean oil-reservoir of an oilfield in China [28]. This strain was gram-positive, facultatively anaerobic, non-motile with no flagellum and had the ability to degradation of petroleum hydrocarbons [28]. Batch growth experimental data showed DQ12-45-1b was able to grow on any single substrate of succinate, acetate and glucose, while formate, lactate and citrate could not serve as the sole carbon and energy source for bacterial growth. Therefore, we chose a simple organic of acetate as the electron donor in this study.

The strain was prepared for bioreduction experiments after aerobic enrichment cultivation in Luria-Bertani medium (LB medium, $10 \mathrm{~g} / \mathrm{L}$ of peptone, $5 \mathrm{~g} / \mathrm{L}$ of yeast extract and $10 \mathrm{~g} / \mathrm{L}$ of $\mathrm{NaCl}$ ) under ambient condition. In bioreduction experiments, strain DQ12-45-1b was cultured anaerobically or aerobically in a medium [29] consisting of (per liter): $6.56 \mathrm{~g}$ sodium acetate, $1.19 \mathrm{~g}$ $\left(\mathrm{NH}_{4}\right)_{2} \mathrm{SO}_{4}, 0.1 \mathrm{~g} \mathrm{MgSO}_{4}, 0.043 \mathrm{~g} \mathrm{CaCl}_{2}, 0.0012 \mathrm{~g} \mathrm{FeSO}_{4}$, and $20 \mathrm{mM} \mathrm{HEPES}$ buffer at $35^{\circ} \mathrm{C}$.

\section{Bioreduction experiments}

Birnessite (final concentration $=0.3 \mathrm{mg} / \mathrm{mL}$ ) was suspended with the culture medium in serum bottles sealed with blue butyl rubber stoppers (for anaerobic) and in flasks (for aerobic) with total volume of $80 \mathrm{~mL}$. In anaerobic experiments, the medium used for anaerobic cultures was made anoxic in serum bottles with $\mathrm{O}_{2}$-free $\mathrm{N}_{2} /$ $\mathrm{CO}_{2}$ gasmix (80:20) and sterilized by autoclaving. Dietzia DQ12-45-1b cell was enriched from LB medium by centrifugation at $4,024 g$, and then washed with sterilized culture medium. This procedure was repeated for three times to remove LB medium, and then the cell pellet was suspended with sterilized culture medium and injected into serum bottles with a fixed concentration. In selected experiments, $0.1 \mathrm{mM}$ anthraquinone-2,6-disulfonate (AQDS) was supplied as an electron shuttle. AQDS solution and HEPES buffer were sterilized by filtration with $0.22 \mu \mathrm{m}$ Millipore filter and injected into the medium with syringes. The control group was identical to the experimental bottles except that cells were replaced with an equal amount of the culture medium (sterile control) 
or inactivated cells (killed control). All treatments were performed in duplicates. All vials were incubated in a constant temperature shaking table at $35^{\circ} \mathrm{C}$. Samplings were conducted in certain time interval in glove box (855AC, Plas-Labs, USA). $3 \mathrm{~mL}$ of suspensions was taken out for $\mathrm{pH}, \mathrm{Mn}^{2+}$ concentration and protein concentration tests to evaluate microbial reduction and the changes of biomass. In aerobic experiments, all processes were identical to those in anaerobic experiments except that oxygen removal was not conducted and the sampling processes were conducted in super clean bench.

\section{Analytical methods}

$\mathrm{Mn}^{2+}$ concentration $\left(C_{l}\right)$ was measured by ICP-OES (Spectroblue, Spectro, Germany) after removing solids by centrifugation of $1 \mathrm{~mL}$ cell-mineral suspension. Protein concentrations were measured by Bradford method [30]. $1 \mathrm{~mL}$ sample was centrifuged at $9,391 \mathrm{~g}$ and the supernatant was discarded. $0.2 \mathrm{M} \mathrm{NaOH}$ was fully mixed with cell pellet, and the mixture was boiled for $12 \mathrm{~min}$ to breakdown the cells and release proteins. The alkali treated sample was then centrifuged and the protein fraction in the supernatant was quantified with the Bradford assay using the standard curve established by bovine serum albumin (BSA) as a standard [30].

$\mathrm{Mn}$ average oxidation state (AOS) of the suspensions was calculated after measuring the total Mn content, $\mathrm{Mn}^{2+}$ content in the medium and $\mathrm{Mn}(\mathrm{III}) / \mathrm{Mn}(\mathrm{IV})$ content, respectively. First, total $\mathrm{Mn}$ content $\left(C_{\text {total }}\right)$ was measured by dissolving $0.5 \mathrm{~mL}$ suspension using $2 \mathrm{~mL}$ $0.25 \mathrm{M}$ hydroxylamine hydrochloride, then diluted to $10 \mathrm{~mL}$ with $2 \% \mathrm{HNO}_{3}$, and then the $\mathrm{Mn}$ concentration was determined by ICP-OES. Aqueous $\mathrm{Mn}^{2+}$ content $\left(C_{l}\right)$ in the solution was also determined by ICP-OES. The amount of $\mathrm{Mn}(\mathrm{IV})$ in the suspension was measured by reaction with the reductive dye, Leucober-belin blue I (LBB) using the standard curve established by $\mathrm{KMnO}_{4}$ as a standard [31]. Oxidized LBB is blue and the color intensity is a function of the amount of $\mathrm{Mn}$ (III)/Mn(IV) being reduced to $\mathrm{Mn}(\mathrm{II})$. The color intensity was measured for optical density at $620 \mathrm{~nm}$ using the spectrophotometer. Amount of electron transfer between $\mathrm{Mn}(\mathrm{III})$ / $\mathrm{Mn}(\mathrm{IV})$ and $\mathrm{Mn}(\mathrm{II})$ was noted as $\mathrm{N}_{\mathrm{e}}$. A concentration of $10 \mu \mathrm{M} \mathrm{KMnO}_{4}$ equaled $50 \mu \mathrm{M}$ electron transfer. According to the amount of total $\mathrm{Mn}, \mathrm{Mn}^{2+}$ and transfer electrons, the Mn AOS was calculated as following equations:

$$
\begin{aligned}
& \operatorname{AOS}_{(\text {Total Mn) }}=2+\mathrm{N}_{e} / \mathrm{C}_{\text {total }} \\
& \operatorname{AOS}_{\text {(insoluble Mn) }}=2+\mathrm{N}_{e} /\left(\mathrm{C}_{\text {total }}-\mathrm{C}_{l}\right)
\end{aligned}
$$

where $\mathrm{AOS}_{(\text {Total Mn) }}$ means AOS of total Mn in the suspensions and $\mathrm{AOS}_{(\text {insoluble } \mathrm{Mn} \text { ) }}$ means $\mathrm{AOS}$ of insoluble
Mn including $\mathrm{Mn}$ in minerals and adsorbed on bacteria or minerals.

It is supposed that all $\mathrm{Mn}(\mathrm{III}) / \mathrm{Mn}$ (IV) were reduced to $\mathrm{Mn}(\mathrm{II})$. And birnessite reduction rate was calculated as following:

$$
\begin{aligned}
\text { Reduction extent }= & \left(\operatorname{AOS}_{(\text {Total Mn }) t}-2\right) / \\
& \left(\operatorname{AOS}_{(\text {Total Mn }) 0}-2\right) \times 100 \%
\end{aligned}
$$

where $\operatorname{AOS}_{(\text {Total Mn)o }}$ means AOS of total Mn at the original time and $\operatorname{AOS}_{(\text {Total Mn)t }}$ means AOS of total Mn after reaction. $\mathrm{AOS}_{(\mathrm{Total} \mathrm{Mn}) 0}$ was measured as 3.92 .

\section{Mineral characterization}

Mineralogical changes after bioreduction were determined by powder X-ray diffraction (XRD). XRD patterns were recorded using $X$ 'pert powder diffractometer (PANalytical B.V., the Netherlands) with $\mathrm{CuK} \alpha$ radiation $(\lambda=0.15406 \mathrm{~nm})$. The instrument was operated at a tube voltage of $40 \mathrm{kV}$ and a tube current of $40 \mathrm{~mA}$. Intensities were measured at $2 \theta=5^{\circ}-70^{\circ}$ with $0.02^{\circ}$ two-theta steps and a count time of $0.3 \mathrm{~s}$ per step.

The mineral micro-morphologies were further characterized by scanning electron microscopy (SEM). Suspensions $(1 \mathrm{~mL})$ were washed by deionized water to remove medium on the mineral surface. The samples were dispersed on polished silicon wafer and then mounted on an aluminum SEM stub via conductive tapes and coated with gold using a Denton Desk II Gold Sputter Coater for SEM observations. The samples were observed under a FEI Quanta 200F SEM with an X-ray energy dispersive spectroscopy (SEM/EDS). The SEM was operated at an accelerating voltage of 10 or $15 \mathrm{kV}$.

The X-ray absorption near-edge data (XANES) at the $\mathrm{Mn}$ K-edge of the original and bioreduced samples were recorded at room temperature in transmission mode using ion chambers at beam line BL14W1 of the Shanghai Synchrotron Radiation Facility (SSRF), China. The station was operated with a $\mathrm{Si}$ (111) double crystal monochromator with a resolution of $1.3 \times 10^{-4} \mathrm{eV}$. Mn K-edge XANES data were collected over the energy range 6,339-6,839 eV in transmission mode. Each powder sample was sandwiched between two pieces of KAPTON tape located on the beam path. During the measurement, the synchrotron was operated at energy of $3.5 \mathrm{GeV}$ and a maximum current of $250 \mathrm{~mA}$. The photon energy was calibrated with the first inflection point of Mn K-edge in Mn metal foil. Data reduction of experimental XANES spectra was carried out using the software ATHANE 1.2.11. Pre-edge background subtraction and XANES normalization were carried out by fitting a linear polynomial to the pre-edge region and a quadratic polynomial to the postedge region of the absorption spectrum. 


\section{Results and discussion}

\section{Anaerobic reduction of birnessite by DQ12-45-1b}

The results of birnessite reduction by DQ12-45-1b were shown in Fig. 1 and summarized in Table 1. As observed in Fig. 1a, significant amounts of $\mathrm{Mn}^{2+}$ were produced in bacterial treatments, which was considerably higher than the concentrations of $\mathrm{Mn}^{2+}$ in sterile control and killed control. In the initial 14 days, the amounts of $\mathrm{Mn}^{2+}$ increased with time and 6, 21 and $42 \%$ of Mn(IV) was reduced with the initial cell concentration of $6.2 \times 10^{8}, 2.5 \times 10^{9}$ and $1.0 \times 10^{10}$ cells $/ \mathrm{mL}$, respectively. By contrast, the chemical reduction extent of $\mathrm{Mn}(\mathrm{IV})$ by acetate was below $5 \%$.
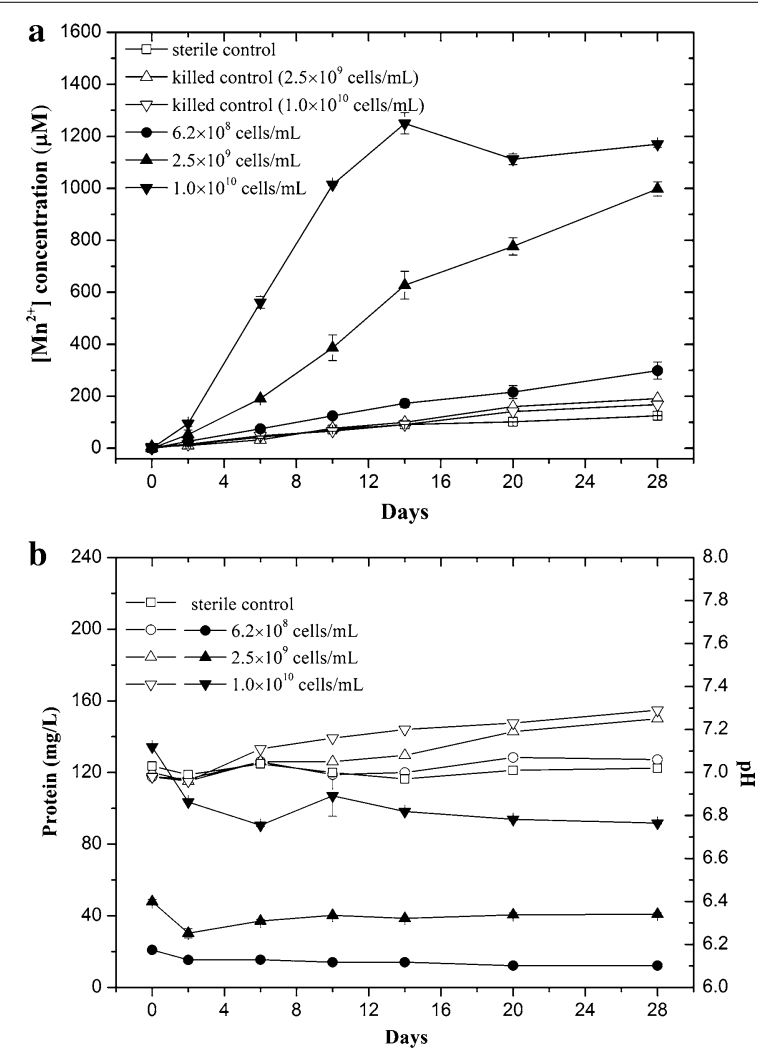

Fig. 1 Aqueous $\mathrm{Mn}^{2+}$ concentrations (a) and protein concentrations (solid symbol)/pH values (hollow symbol) (b) during anaerobic birnessite reduction with different initial cell concentrations.
Since changes in Mn reduction rate could be roughly estimated from $\mathrm{Mn}^{2+}$ release rate, three stages of $\mathrm{Mn}$ reduction process could be approximately obtained from Fig. 1a. The first stage is the initial 2 days, when $\mathrm{Mn}^{2+}$ concentration increased but with a relatively lower rate than the following several days. $\mathrm{Mn}^{2+}$ release rates with initial cell concentrations of $6.2 \times 10^{8}$ and $2.5 \times 10^{9}$ during 2-14 days and that with $1.0 \times 10^{10}$ cells $/ \mathrm{mL}$ during $2-10$ days was calculated to be $12.2,48.0$ and $114.9 \mu \mathrm{M} /$ day, respectively, showing a positive correlation with the inoculated cell density. However, $\mathrm{Mn}^{2+}$ release rates after 14 days decreased to 9.1 and $26.5 \mu \mathrm{M}$ /day in the treatments with two lower cell concentrations, indicating the bacterial activity associated with $\mathrm{Mn}$ bioreduction went down. Even a slight decrease in $\mathrm{Mn}^{2+}$ concentration after 14 days was observed with the highest inoculation concentration of $1.0 \times 10^{10}$ cells $/ \mathrm{mL}$, suggesting the bioreduction possibly stopped. Besides, tiny amounts of particles were observed in the medium after 14 days. All these evidences indicated the bioreduction of $\mathrm{Mn}$ with the highest cell concentration of $1.0 \times 10^{10}$ cells $/ \mathrm{mL}$ was close to completion at the 14th day. Consistently, the AOS of the residuals were measured to be 2.22 (Table 1) and found to be approaching 2 . The slight decrease of $\mathrm{Mn}^{2+}$ concentration after 14 days would be explained by adsorption of $\mathrm{Mn}(\mathrm{II})$ onto the cell or residual mineral surface, or else by forming $\mathrm{Mn}$ (II)/Mn(III) minerals [3234]. So, in bacterial treatment with cell concentration of $1.0 \times 10^{10}$ cells $/ \mathrm{mL}$, almost all $\mathrm{Mn}(\mathrm{IV})$ in birnessite was reduced to $\mathrm{Mn}(\mathrm{II})$ after 14 days and part of produced $\mathrm{Mn}(\mathrm{II})$ was present as insoluble state. There was a positive relationship between the $\mathrm{Mn}$ reduction rate and the cell concentration, that the final reduction extent of birnessite was 33, 53 and 93\% (Fig. 1; Table 1), corresponding to the cell concentration of $6.2 \times 10^{8}, 2.5 \times 10^{9}$ and $1.0 \times 10^{10}$ cells $/ \mathrm{mL}$, respectively.

Previous studies showed Shewanella oneidensis MR-1 could couple its anaerobic growth to $\mathrm{Mn}(\mathrm{IV})$ reduction and gain energy from the redox reaction including organics oxidation and metal reduction [16]. Here, acetate served as the electron donor, and birnessite served as the electron acceptor. So, the total reaction could be given as:

Table 1 Anaerobic reduction of birnessite under different cell concentrations

\begin{tabular}{lllll}
\hline Cell concentration (cell/mL) & OOS $_{(\text {Total } \mathbf{~ n n})}$ & $\mathbf{A O S}_{\text {(insoluble } \mathbf{~ n})}$ & $\mathbf{M n}^{\mathbf{2 +}} / \mathbf{M n}_{\text {(total) }}(\%)$ & Reduction extent $(\%)$ \\
\hline $6.2 \times 10^{8}$ & 3.29 & 3.44 & 10 & 33 \\
$2.5 \times 10^{9}$ & 2.90 & 3.35 & 33 & 53 \\
$1.0 \times 10^{10}$ & 2.13 & 2.22 & 39 & 93 \\
0 & 3.83 & 3.91 & 4 & 5 \\
\hline
\end{tabular}

All samples were biotreated for 28 days. 


$$
\begin{aligned}
& 3 \mathrm{MnO}_{2}+\mathrm{CH}_{3} \mathrm{COO}^{-}+\mathrm{H}_{2} \mathrm{O} \\
& \longrightarrow 3 \mathrm{Mn}^{2+}+2 \mathrm{HCO}_{3}^{-}+3 \mathrm{OH}^{-}
\end{aligned}
$$

However, the anaerobic reduction of birnessite by DQ12-45-1b were found to be unaccompanied by bacterial growth. In the presence of birnessite as the sole electron acceptor, the concentrations of $\mathrm{Mn}^{2+}$ continuously increased in all three bacterial treatments during the stable bioreduction stage (day 2-14), while the bacterial protein concentration kept stable (Fig. 1b). Particularly, the $\mathrm{Mn}^{2+}$ release rates were found to be in good proportion to the protein concentrations (Fig. 2). Therefore, we can confirm the anaerobic reduction of birnessite by DQ12-45-1b was not a direct biological process linking Mn reduction with bacterial growth. Considering the results of killed control and the positive correlation between the $\mathrm{Mn}^{2+}$ release rates and protein concentrations, we speculate the bioreduction process may be an enzymatic reaction, which needs further demonstration.

\section{Aerobic reduction of birnessite by DQ12-45-1b}

Under aerobic conditions, $\mathrm{Mn}^{2+}$ concentration of sterile treatment gradually increased over the experiment (Fig. 3a) due to acetate reduction. In treatments with the initial inoculation cell concentration of $6.2 \times 10^{8}$, $2.5 \times 10^{9}$ and $1.0 \times 10^{10}$ cells $/ \mathrm{mL}, \mathrm{Mn}^{2+}$ concentration in the initial 2 days sharply increased to 33.0, 98.7 and $180.0 \mu \mathrm{M}$, respectively. The initial $\mathrm{Mn}^{2+}$ release rates also showed a positive correlation with the inoculated cell density. Meanwhile, the $\mathrm{pH}$ drastically went up from 6.9 to 8.3 for the two higher cell concentrations even in the presence of HEPES buffer, which lead to the quick precipitation, re-adsorption of $\mathrm{Mn}$ (II) on the mineral surface

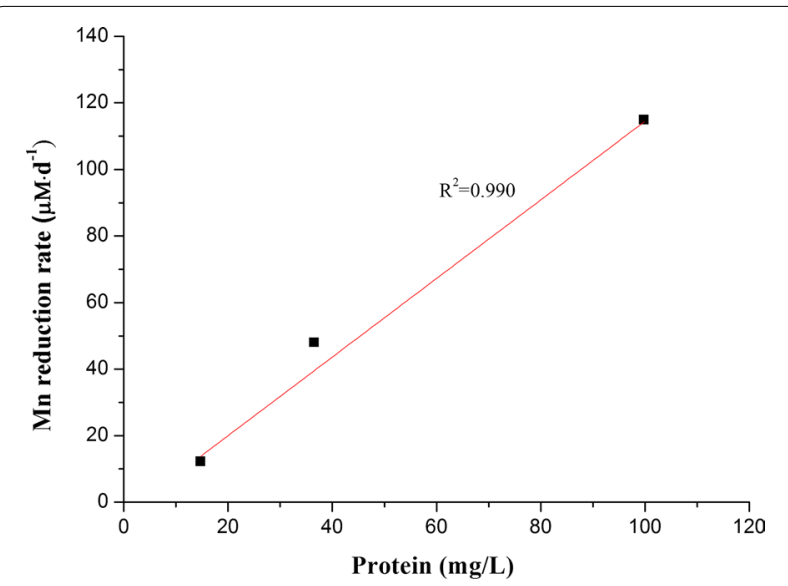

Fig. 2 A positive relationship between protein and $\mathrm{Mn}^{2+}$ release rate (abscissa values were the mean values of proteins in 2-14 days).
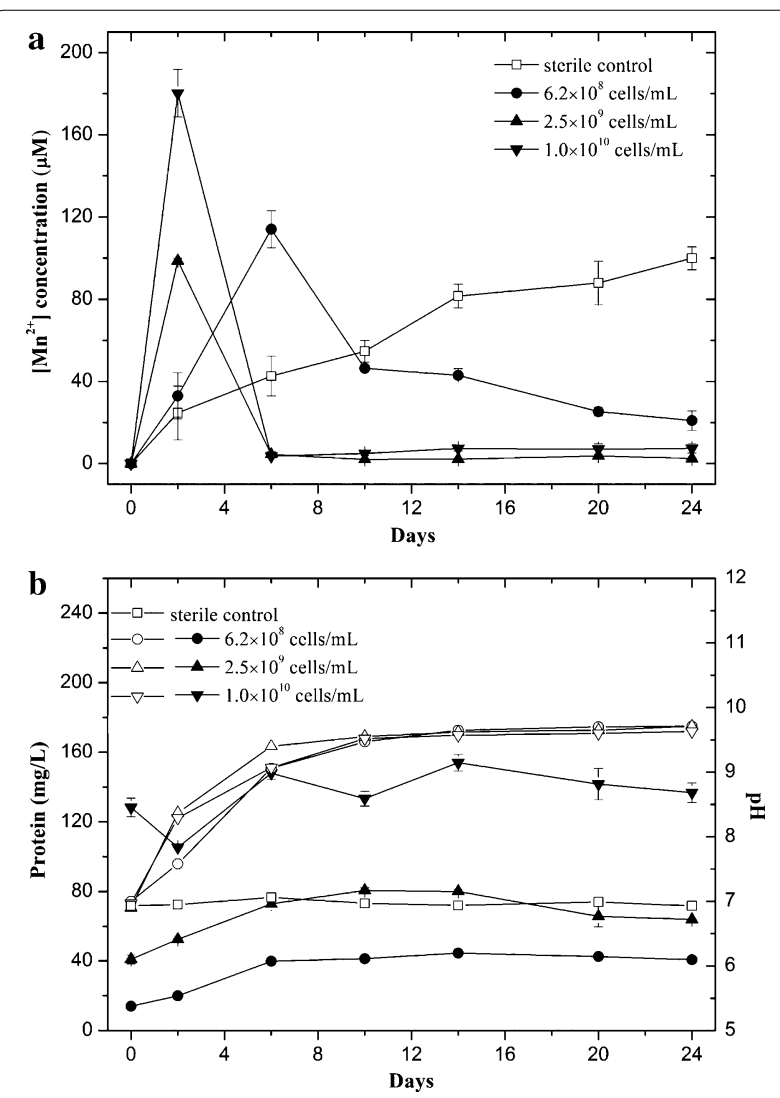

Fig. 3 Aqueous $\mathrm{Mn}^{2+}$ concentration (a) and protein concentration (solid symbol)/pH value (hollow symbo/s) (b) during aerobic birnessite reduction with different initial cell concentration.

or re-oxidation of $\mathrm{Mn}(\mathrm{II})$ as reflected by the abrupt drop of $\mathrm{Mn}^{2+}$ concentration to zero in the following days. As expected, some white precipitations were observed in the suspensions with two higher cell concentrations of $2.5 \times 10^{9}$ and $1.0 \times 10^{10}$ cells $/ \mathrm{mL}$, indicating the formation of new minerals related to $\mathrm{Mn}$ reduction. In the medium with the lowest cell concentration of $6.2 \times 10^{8}$ cells $/ \mathrm{mL}$, both the maximum $\mathrm{Mn}^{2+}$ generation and the most drastic change in $\mathrm{pH}$ were recorded later than in the equivalent treatments with higher cell concentration (approximately at the 6th day). And after the 6th day, the $\mathrm{Mn}^{2+}$ concentration did not undergo a sudden change to zero but gradually decreased. No visible precipitates were observed in this treatment.

Bacterial growth under aerobic condition was indicated by time-course increase of protein and $\mathrm{pH}$ (Fig. 3b). When grown in pure culture with $\mathrm{O}_{2}$ as the terminal electron acceptor, the DQ12-45-1b strains were found to be able to increase the $\mathrm{pH}$ value from neutral to alkaline scales (data not shown). Therefore, the rapider increase in both soluble $\mathrm{Mn}^{2+}$ and $\mathrm{pH}$ values in bacterial treatments 
than those in sterile control, as well as the obvious positive correlation between the inoculated cell concentration and $\mathrm{Mn}$ reduction extent indicated the aerobic $\mathrm{Mn}$ reduction was correlated with the bacterial growth. In a separate experimental batch, which was to examine the relationship between the acetate consumption and cell concentration, we observed the depletion of acetate at around the 6th day (Additional file 1: Figure S1). So, along with the depletion of carbon source, the bacterial growth stagnated, and the protein concentration did not increase any more (Fig. 3b). The $\mathrm{pH}$ went stable and finally maintained at 9.6-9.7 (Fig. 3b).

After 24 days, the AOS of insoluble $\mathrm{Mn}$ in the system with initial cell concentrations of $2.5 \times 10^{9}$ and $1.0 \times 10^{10}$ cells $/ \mathrm{mL}$ were 3.44 and 3.21 , corresponding to 25 and $37 \%$ of Mn reduction, respectively (Table 2). The actual $\mathrm{Mn}$ reduction extent should be higher than the experimental values, because under alkaline condition, re-oxidation of $\mathrm{Mn}$ (II) by $\mathrm{O}_{2}$ is feasible [35, 36]. In comparison, the AOS of insolubles with initial cell concentration of $6.2 \times 10^{8}$ cells $/ \mathrm{mL}$ was 3.92 (Table 2), the same as the original birnessite. Although there were some $\mathrm{Mn}^{2+}$ continuously released in the initial 6 days of $6.2 \times 10^{8}$ cells $/ \mathrm{mL}$ treatment, the $\mathrm{Mn}^{2+}$ concentration gradually decreased in the following days (Fig. 3a).

Comparing $\mathrm{Mn}$ bioreduction in the presence and absence of $\mathrm{O}_{2}$, it could be found that $\mathrm{Mn}$ reduction extents under aerobic condition were much lower than those under anaerobic conditions, although stain DQ1245-1b grew more vigorous under aerobic conditions. These findings suggested $\mathrm{O}_{2}$ interfered with birnessite reduction, not only as an alternative electron acceptor to compete with $\mathrm{Mn}(\mathrm{IV})$ reduction, but also as an oxidizer leading to re-oxidation of $\mathrm{Mn}$ (II) in alkaline $\mathrm{pH}$.

\section{Effect of AQDS on reduction of birnessite}

Addition of the humic acid analog AQDS generally enhanced $\mathrm{Mn}^{2+}$ release rates under anaerobic condition (Fig. 4a). The $\mathrm{Mn}^{2+}$ release rate with AQDS was observed to be approximately one time higher than that without AQDS in the initial 2-14 days and more than $60 \%$ higher in 14-28 days (Table 3). Consistently, the AOS of the

Table 2 Aerobic reduction of birnessite under different cell concentrations

\begin{tabular}{lllll}
\hline $\begin{array}{l}\text { Cell concentra- } \\
\text { tion (cell/mL) }\end{array}$ & $\mathbf{A O S}_{\text {(Total Mn) }}$ & $\mathbf{A O S}_{\text {(insoluble Mn) }}$ & $\begin{array}{l}\mathbf{M n}^{2+} / \\
\mathbf{M n}_{\text {(total) }}\end{array}$ & $\begin{array}{l}\text { Reduction } \\
\text { extent (\%) }\end{array}$ \\
\hline $6.2 \times 10^{8}$ & 3.91 & 3.92 & $<1$ & $<1$ \\
$2.5 \times 10^{9}$ & 3.44 & 3.44 & $<1$ & 25 \\
$1.0 \times 10^{10}$ & 3.21 & 3.21 & $<1$ & 37 \\
0 & 3.88 & 3.94 & 3 & 3 \\
\hline
\end{tabular}

All samples were biotreated for 24 days.
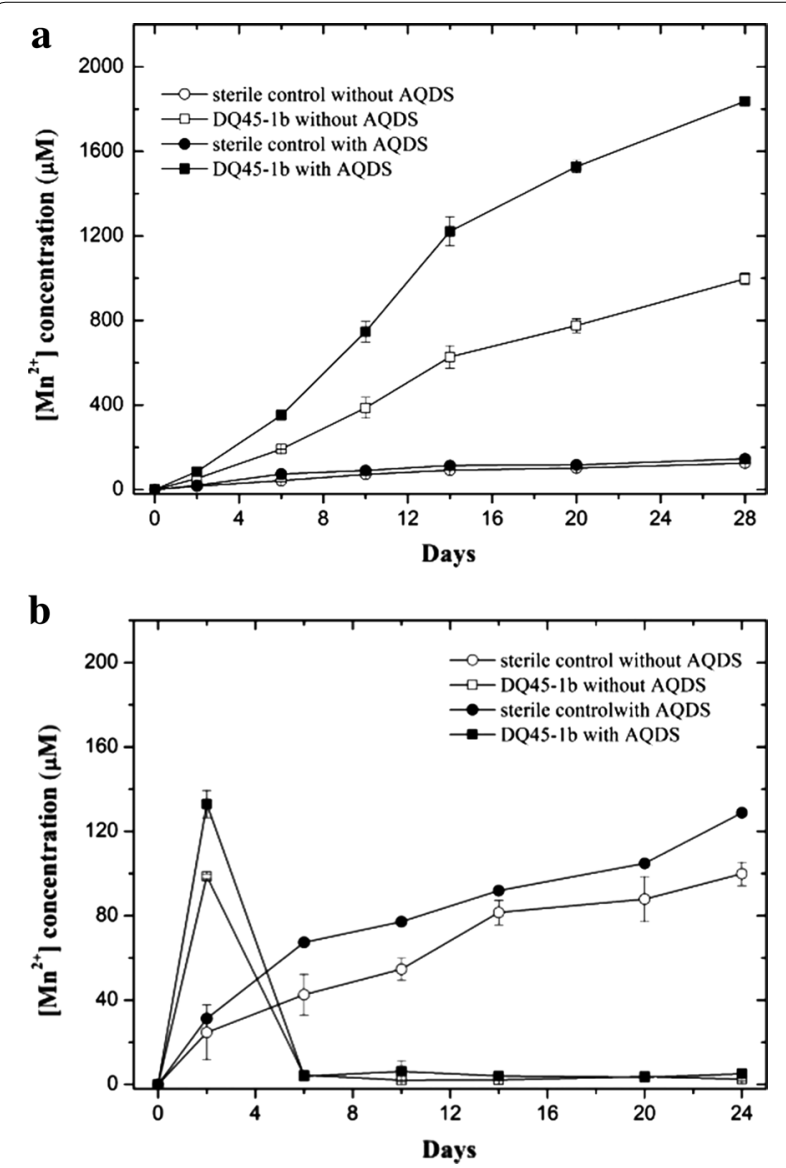

Fig. 4 Aqueous $\mathrm{Mn}^{2+}$ concentration during birnessite reduction with/without AQDS under anaerobic condition (a) and aerobic condition (b)

insolubles decreased from the initial 3.92 to 2.57 with AQDS and to 3.35 without AQDS.

Under aerobic condition, a slight enhancement of $\mathrm{Mn}^{2+}$ release rates was observed in the presence of AQDS in the first 2 days (Fig. 4b). However, unlike in anaerobic experiments, the addition of AQDS did not enhance the Mn reduction extent, and the AOS of the insolubles was 3.80 with AQDS and 3.44 without AQDS (Table 3).

It is believed that AQDS could enhance the rate and extent of microbial metal reduction by shuttling electrons from bacteria to mineral surfaces and thus eliminating the requirement for direct contact of bacteria with electron acceptors [18, 37-40]. The possible reduction of AQDS by cells gave rise to biogenic $\mathrm{AH}_{2} \mathrm{DS}$ (reduced state of AQDS), which then undertook chemical reduction of Mn(IV) [38, 40]. This mechanism could explain the observed increase in both the rate and extent of $\mathrm{Mn}$ reduction under anaerobic condition. Under aerobic condition, electrons were transferred to AQDS prior to birnessite and $\mathrm{O}_{2}$ [41]. Birnessite and $\mathrm{O}_{2}$ competed 
Table 3 Microbial Mn reduction with or without AQDS

\begin{tabular}{|c|c|c|c|c|c|c|}
\hline & AQDS & $\begin{array}{l}\mathrm{Mn}^{2+} \text { release rate } \\
\text { in } 2-14 \text { days }(\mu \mathrm{M} / \text { day })\end{array}$ & $\begin{array}{l}\mathrm{Mn}^{2+} \text { release rate } \\
\text { in } 14-28 \text { days ( } \mu \mathrm{M} / \text { day) }\end{array}$ & $\operatorname{AOS}_{\text {(total Mn) }}$ & $\mathrm{AOS}_{\text {(insoluble Mn) }}$ & $\begin{array}{l}\text { Reduction } \\
\text { extent (\%) }\end{array}$ \\
\hline \multirow[t]{2}{*}{ Anaerobic } & - & 48.0 & 26.5 & 2.90 & 3.35 & 53 \\
\hline & + & 95.1 & 43.7 & 2.17 & 2.57 & 91 \\
\hline \multirow[t]{2}{*}{ Aerobic } & - & I & / & 3.44 & 3.44 & 25 \\
\hline & + & / & / & 3.80 & 3.80 & 6 \\
\hline
\end{tabular}

Samples were biotreated with cell concentration of $2.5 \times 10^{9}$ cell $/ \mathrm{mL}$ for 28 days under anaerobic conditions and 24 days under aerobic conditions; $(+)$ means with AQDS; (-) means without AQDS; (/) means not detected.

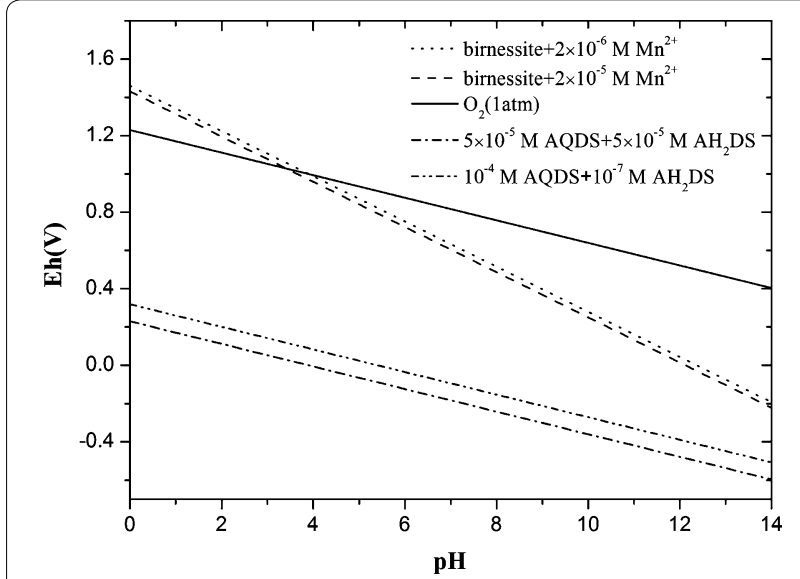

Fig. 5 Reduction potential of $\mathrm{O}_{2}$, birnessite (at $2 \times 10^{-5}$ and $2 \times 10^{-6} \mathrm{M} \mathrm{Mn}^{2+}$ activity) [42] and AQDS (at $5 \times 10^{-5} \mathrm{M} \mathrm{AQDS}$ plus $5 \times 10^{-5} \mathrm{M} \mathrm{AH}_{2} \mathrm{DS}$ and $10^{-4} \mathrm{AQDS} \mathrm{M}$ plus $10^{-7} \mathrm{M} \mathrm{AH}_{2} \mathrm{DS}$ activity) [43] as a function of $\mathrm{pH}$.

to accept electrons from biogenic $\mathrm{AH}_{2} \mathrm{DS}$. At neutral to alkaline environment, the redox potential of $\mathrm{O}_{2}$ was higher than that of birnessite, especially at alkaline $\mathrm{pH}$ (Fig. 5). So the biogenic $\mathrm{AH}_{2} \mathrm{DS}$ may be preferentially to be oxidized by $\mathrm{O}_{2}$. In aerobic bio-treatment, AQDS as an electron shuttle essentially accelerated electron transfer between bacteria and $\mathrm{O}_{2}$, which finally lead to the inhibition of $\mathrm{Mn}(\mathrm{IV})$ reduction.

\section{Mineral characterization of bioreduced samples}

Under anaerobic condition, no visible color change in the residual insolubles was observed and the quantity of insoluble in bio-treatments obviously decreased after the experiments. The XRD patterns of residuals in all anaerobic bio-treatments showed the characteristic peaks of birnessite (JCPDS: 23-1239) (Fig. 6a), but with significant loss in peak strength as compared to sterile controls, which was in agreement with the visual observations of bio-induced dissolution of birnessite. No other secondary minerals were detected by XRD.

It was also found that the peak strength decreased as the cell concentration increased, which was attributed to the improved reduction extent of birnessite by higher cell concentration (Fig. 1; Table 1). Besides, the addition
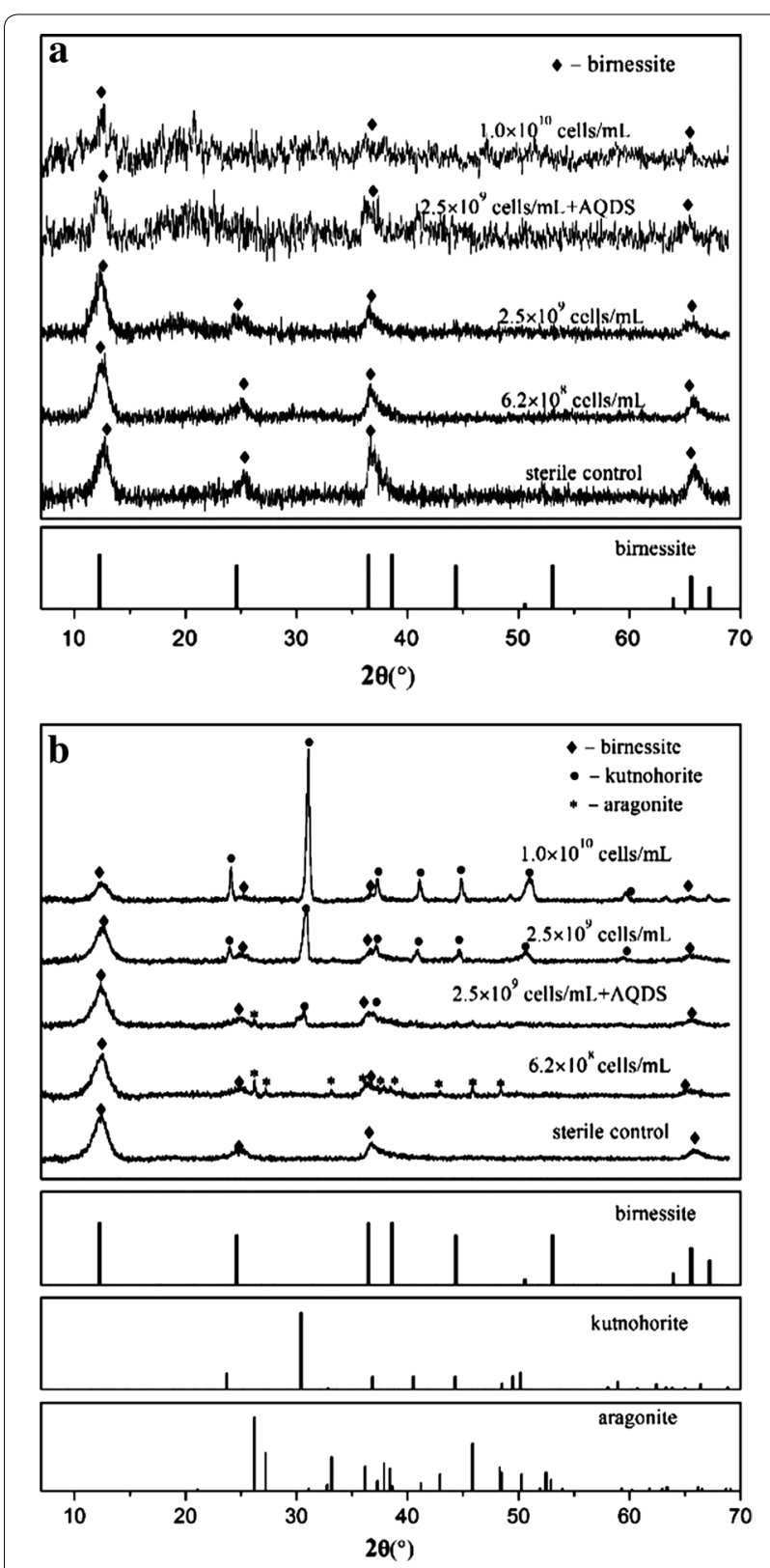

Fig. 6 XRD patterns of bioreduced samples under anaerobic (a) and aerobic condition $(\mathbf{b})$. 


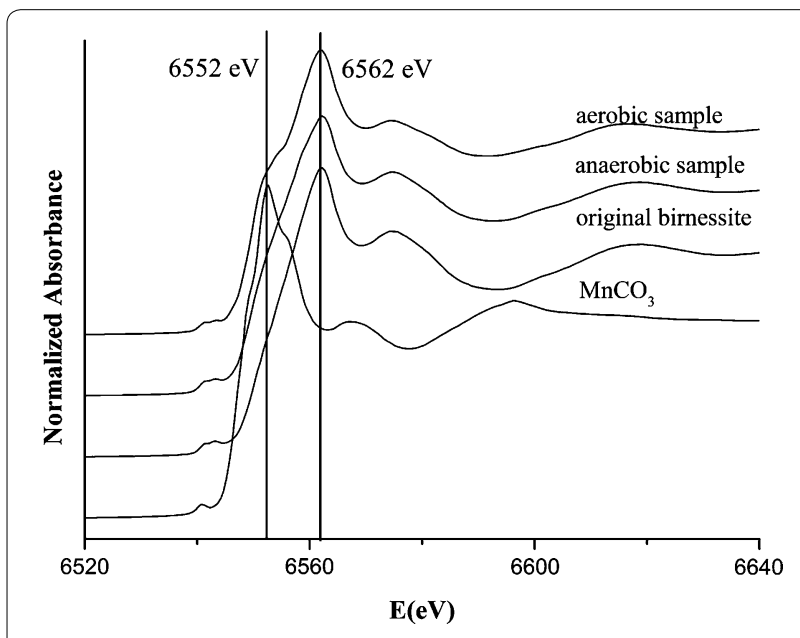

Fig. 7 XANES spectra of original birnessite and bioreduced samples in the system with an initial cell concentration of $2.5 \times 10^{9}$ cells $/ \mathrm{mL}$.

of AQDS also significantly accelerated the microbial Mn reduction (Fig. 4a), thereby resulted in more complete dissolution of birnessite and poorer quality XRD patterns of residuals (Fig. 6a).

Further, by comparing the XANES spectra of the residuals in anaerobic bio-treatment to the original birnessite (Fig. 7), we can find a similar peak assigned to $\mathrm{Mn}(\mathrm{IV})$ at $6,562 \mathrm{eV}$ and a weak shoulder assigned to $\mathrm{Mn}(\mathrm{II})$ at $6,552 \mathrm{eV}[44,45]$, the latter of which was probably ascribed to adsorbed $\mathrm{Mn}$ (II) from birnessite reduction. Taken together, all these data demonstrated the anaerobic reduction of birnessite by DQ12-45-1b released $\mathrm{Mn}$ (II) and caused the dissolution of birnessite.

In aerobic bio-treatments, white suspensions in strong color contrast to black birnessite were observed, indicating the possible precipitation of new mineral phases. Under SEM, some spindle-like aggregations were found and their surface appeared with many holes whose size and shape were very similar to a single cell (Fig. 8b). The EDS results (Fig. 8c) indicated the aggregations mainly consisted of $\mathrm{Mg}, \mathrm{Ca}, \mathrm{Mn}, \mathrm{C}$ and $\mathrm{O}$, which was very different from the composition of birnessite. Consistently, XRD patterns of aerobic bioreduced samples showed several new peaks at $2 \theta=2.39^{\circ}, 30.8^{\circ}$ and $50.7^{\circ}$, which were assigned to (012), (104) and (116) reflections of kutnohorite [ $\mathrm{Ca}(\mathrm{Mn}, \mathrm{Mg})\left(\mathrm{CO}_{3}\right)_{2}$; JCPDS: 084-1290], respectively (Fig. 6b). Thereafter, an obvious shoulder feature at approximately $6,552 \mathrm{eV}$ in the XANES spectra of the residuals in aerobic bio-treatment verified the formation of $\mathrm{Mn}(\mathrm{II})$-bearing minerals.

With the growth of stain DQ12-45-1b, carbon dioxide accumulation from the oxidation of acetate and the increased $\mathrm{pH}$ value caused high $\mathrm{CO}_{3}{ }^{2-}$ activity, therefore leading to the precipitation of carbonate minerals. Accordingly, the quantity of produced carbonates was positively associated with the inoculated cell concentration (Fig. 6b). Surprisingly, only the sample with the lowest cell concentration of $6.2 \times 10^{8}$ cells $/ \mathrm{mL}$ did not show any peaks of kutnohorite, but showed the existence of aragonite $\left(\mathrm{CaCO}_{3}\right.$; JCPDS: 05-0453) (Fig. 6b). This phenomenon was in agreement with the considerably low concentration of $\mathrm{Mn}^{2+}$ (Fig. 3a) and high value of AOS (Table 2) as measured before. $\mathrm{Mn}(\mathrm{II})$ produced by bioreduction combined with carbon dioxide produced by acetate metabolism, as well as an alkaline $\mathrm{pH}$ environment given by cell growth, finally resulted in the formation of Mn(II)-bearing carbonate (kutnohorite). The concentration of $\mathrm{Mn}(\mathrm{II})$ produced in bio-treatment with cell concentration of $6.2 \times 10^{8}$ cells $/ \mathrm{mL}$ was too low to thermodynamically favor the formation of kutnohorite. And the insufficient supply of $\mathrm{Mn}$ (II) resulted in the formation of aragonite instead. Although $\mathrm{Mn}$ (II) re-oxidation by $\mathrm{O}_{2}$ competed with $\mathrm{Mn}$ reduction in aerobic treatments, once the net content of produced $\mathrm{Mn}(\mathrm{II})$ reached a proper level, $\mathrm{Mn}(\mathrm{II})$ would quickly precipitate and not allow
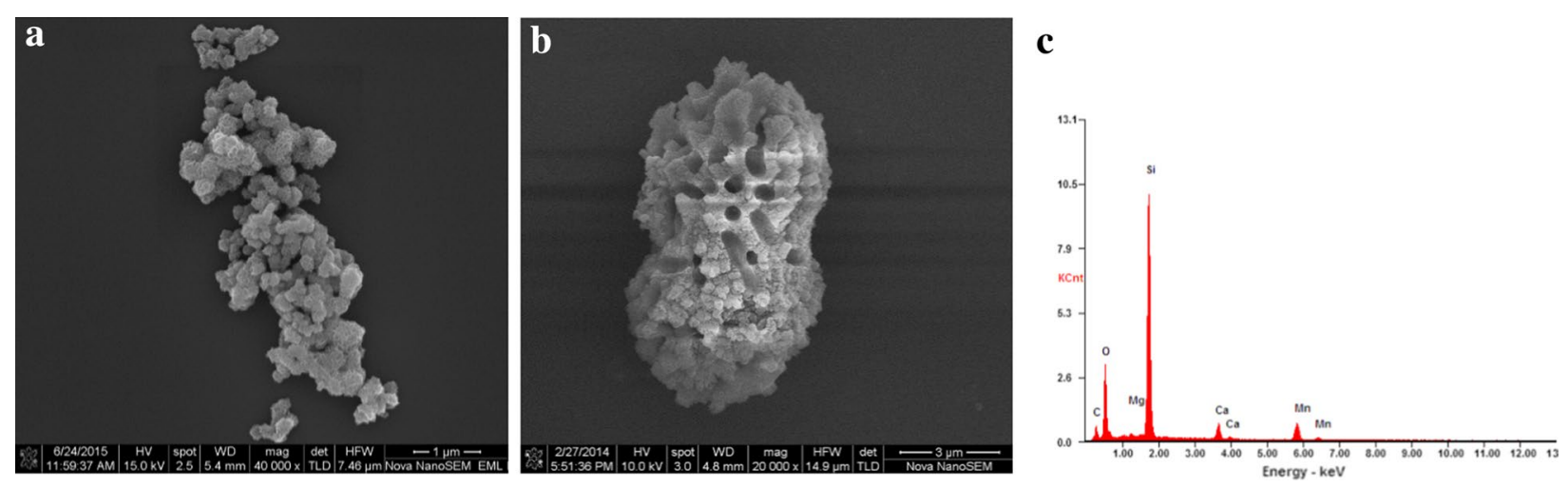

Fig. 8 SEM of original and bioreduced samples. a SEM of original globular-flower-like birnessite; b SEM of spindle-shape mineral after microbial reduction under aerobic condition; c EDS of spindle-shape mineral after microbial reduction under aerobic condition. 
for further oxidation by $\mathrm{O}_{2}$. This point could be drawn from the two bio-systems with higher cell concentration. Accordingly, the system with the highest cell concentration of $1.0 \times 10^{10}$ cells $/ \mathrm{mL}$ gave rise to the most amount of kutnohorite as indicated by XRD results (Fig. 6b). Since DQ12-45-1b preferentially transferred electrons to AQDS and the presence of AQDS facilitated $\mathrm{O}_{2}$ reduction but interfered $\mathrm{Mn}$ reduction, a relatively smaller proportion of kutnohorite was obtained in the presence of AQDS as compared to that without addition of AQDS (Fig. 6b).

\section{Conclusion}

Birnessite reduction in presence of DQ12-45-1b was observed in both anaerobic and aerobic conditions, and the $\mathrm{Mn}(\mathrm{IV})$ reduction proceeded at a more rapid rate when inoculated with higher cell concentration. The extent of $\mathrm{Mn}(\mathrm{IV})$ reduction in aerobic conditions was lower than that in anaerobic conditions due to the re-oxidation by oxygen or competition with oxygen respiration. In anaerobic conditions, addition of AQDS improved $\mathrm{Mn}(\mathrm{IV})$ reduction extent and accelerated $\mathrm{Mn}(\mathrm{II})$ production rate, which ultimately promoted birnessite dissolution. In aerobic treatments, indirect effects ascribed from bacterial metabolism, such as changes of $\mathrm{pH}$, consumption of oxygen and release of metabolites etc., gave a profound influence on the balance between $\mathrm{Mn}(\mathrm{IV})$ reduction and $\mathrm{Mn}(\mathrm{II})$ re-oxidation, which ultimately lead to the final AOS of Mn oxides, and decided the insoluble products. The presence of AQDS and $\mathrm{O}_{2}$ was demonstrated to interfere $\mathrm{Mn}(\mathrm{IV})$ reduction and result in low reduction extent of birnessite. The formation of $\mathrm{Mn}$ (II)-bearing carbonate (kutnohorite) in aerobic conditions depended on how fast and how far birnessite was reduced to give rise to $\mathrm{Mn}(\mathrm{II})$ available for precipitation.

\section{Additional file}

Additional file 1: Figure S1. Acetate concentrations during aerobic birnessite reduction with different initial cell concentrations.

\section{Authors' contributions}

$\mathrm{HZ}$ co-planned experiments, carried out the experiments and drafted the manuscript. YL co-planned experiments, did revision and gave final approval of the version to be published. XW, HD and CZ contributed to the interpretation of the results and helped polish the manuscript. AL participated in the design of the study and funded the study. CW helped design the study. XW helped carry out the analyses of Mn concentration. YN and XW isolated the bacteria. All authors read and approved the final manuscript.

\section{Author details}

${ }^{1}$ The Key Laboratory of Orogenic Belts and Crustal Evolution, School of Earth and Space Sciences, Peking University, Beijing 100871, People's Republic of China. ${ }^{2}$ Department of Energy and Resources Engineering, College of Engineering, Peking University, Beijing 100871, People's Republic of China.

\section{Acknowledgements}

This work was funded by the National Basic Research Pro-

gram of China (973 Program) (Grant no. 2014CB846001) and the National Natural Science Foundation of China (Grant no. 41230103, 41272003 and 41402032). The authors thank beamline BL14W1 (Shanghai Synchrotron Radiation Facility) for providing the beam time.

\section{Compliance with ethical guidelines}

\section{Competing interests}

The authors declare that they have no competing interests.

Received: 31 December 2014 Accepted: 21 July 2015

Published online: 08 August 2015

\section{References}

1. Turekian KK, Wedepohl KH (1961) Distribution of the elements in some major units of the Earth's crust. Geol Soc Am Bull 72:175-192

2. Post JE (1999) Manganese oxide minerals: crystal structures and economic and environmental significance. Proc Natl Acad Sci USA 96:3447-3454

3. Nelson YM, Lion LW (2003) Formation of biogenic manganese oxides and their influence on the scavenging of toxic trace metals. In: Selim HM, Kingerly WL (eds) Geochemical and hydrological reactivity of heavy metals in soils. CRC Press, Boca Raton, pp 169-186

4. Tebo BM, Bargar JR, Clement BG, Dick GJ, Murray KJ, Parker D et al (2004) Biogenic manganese oxides: properties and mechanisms of formation. Annu Rev Earth PI Sc 32:287-328

5. O'Reilly SE, Hochella MF (2003) Lead sorption efficiencies of natural and synthetic Mn and Fe-oxides. Geochim Cosmochim Acta 67:4471-4487

6. Sherman DM, Peacock CL (2010) Surface complexation of Cu on birnessite (d-MnO2): controls on $\mathrm{Cu}$ in the deep ocean. Geochim Cosmochim Acta 74:6721-6730

7. White JR, Driscoll CT (1987) Manganese cycling in an acidic Adirondack lake. Biogeochemistry 3:87-103

8. Slomp CP, Malschaert JFP, Lohse L, Van Raaphorst W (1997) Iron and manganese cycling in different sedimentary environments on the North Sea continental margin. Cont Shelf Res 17:1083-1117

9. Ukrainczyk L, McBride MB (1992) Oxidation of phenol in acidic aqueous suspensions of manganese oxide. Clay Clay Miner 40:157-166

10. Lovley DR (1993) Dissimilatory metal reduction. Annu Rev Microbiol 7:263-290

11. Lovley DR, Holmes DE, Nevin KP (2006) Dissimilatory Fe (III) and Mn (IV) reduction. Adv Microb Physiol 49:219-286

12. Jones C, Crowe SA, Sturm A, Leslie KL, Maclean LCW, Katsev S et al (2011) Biogeochemistry of manganese in ferruginous lake matano, indonesia. Biogeosciences 8:2977-2991

13. Bargar JR, Tebo BM, Bergmann U, Webb SM, Glaetzel P, Chiu VQ et al (2005) Biotic and abiotic products of Mn(II) oxidation by spores of the marine Bacillus sp. strain SG-1. Am Mineral 90:143-154

14. Jürgensen A, Widmeyer JR, Gordon RA, Bendell-Young LI, Moore MM, Crozier ED (2004) The structure of the manganese oxide on the sheath of the bacterium Leptothrix discophora: an XAFS study. Am Mineral 89:1110-1118

15. Villalobos M, Bargar JR, Sposito G (2005) Trace metal retention on biogenic manganese oxide nanoparticles. Elements 1:223-226

16. Myers CR, Nealson KH (1988) Bacterial manganese reduction and growth with manganese oxide as the sole electron acceptor. Science 240:1319-1321

17. Lovley DR, Phillips EJP (1988) Novel mode of microbial energy metabolism: organic carbon oxidation coupled to dissimilatory reduction of iron or manganese. Appl Environ Microbiol 54:1472-1480

18. Lovely D (2013) Dissimilatory Fe(III)-and Mn(IV)-reducing prokaryotes. In: Rosenberg E, DeLong EF, Lory S, Stackebrandt E, Thompson F (eds) The prokaryotes. CBS Publishers, New Delhi, pp 287-308

19. Mehta T, Coppi MV, Childers SE, Lovley DR (2005) Outer membrane c-type cytochromes required for Fe(III) and Mn(IV) oxide reduction in Geobacter sulfurreducens. Appl Environ Microbiol 71:8634-8641 
20. Aklujkar M, Coppi MV, Leang C, Kim BC, Chavan MA, Perpetua LA et al (2013) Proteins involved in electron transfer to Fe(III) and Mn(IV) oxides by Geobacter sulfurreducens and Geobacter uraniireducens. Microbiology 159:515-530

21. Kouzuma A, Hashimoto K, Watanabe K (2012) Roles of siderophore in manganese-oxide reduction by Shewanella oneidensis MR-1. FEMS Microbiol Lett 326:91-98

22. Shi L, Squier TC, Zachara JM, Fredrickson JK (2007) Respiration of metal (hydr)oxides by Shewanella and Geobacter: a key role for multihaem c-type cytochromes. Mol Microbiol 65:12-20

23. Ghiorse WC (1984) Biology of iron and manganese depositing bacteria. Annu Rev Microbiol 38:515-550

24. Trimble RB, Ehrlich HL (1970) Bacteriology of manganese nodules. IV. Induction of a $\mathrm{MnO}_{2}$-reductase system in a marine bacillus. Appl Microbiol 19:966-972

25. Lovley DR, Coates JD, Blunt-Harris EL, Phillips EJP, Woodward JC (1996) Humic substances as electron acceptors for microbial respiration. Nature 382:445-448

26. Ruebush SS, Icopini GA, Brantley SL, Tien M (2006) In vitro enzymatic reduction kinetics of mineral oxides by membrane fractions from Shewanella oneidensis MR-1. Geochim Cosmochim Acta 70:56-70

27. McKenzie RM (1971) The synthesis of birnessite, cryptomelane, and some other oxides and hydroxides of manganese. Mineral Mag 38:493-502

28. Wang XB, Chi CQ, Nie Y, Tang YQ, Tan Y, Wu G et al (2011) Degradation of petroleum hydrocarbons (C6-C40) and crude oil by a novel Dietzia strain. Bioresour Technol 102:7755-7761

29. Kostka JE, Luther GW, Nealson KH (1995) Chemical and biological reduction of $\mathrm{Mn}(\mathrm{III})$-pyrophosphate complexes epotential importance of dissolved Mn(III) as an environmental oxidant. Geochim Cosmochim Acta 59:885-894

30. Zor T, Selinger Z (1996) Linearization of the Bradford protein assay increases its sensitivity: theoretical and experimental studies. Anal Biochem 236:302-308

31. Krumbein WE, Altmann HJ (1973) A new method for the detection and enumeration of manganese oxidizing and reducing microorganisms. Helgolinder wiss Meeresunters 25:347-356

32. Fischer TB, Heaney PJ, Jang JH, Ross DE, Brantley SL, Post JE et al (2008) Continuous time-resolved X-ray diffraction of the biocatalyzed reduction of Mn oxide. Am Mineral 93:1929-1932

33. Bratina BJ, Stevenson BS, Green WJ, Thomas MS (1998) Manganese reduction by microbes from oxic regions of the lake Vanda (Antarctica) water column. Appl Environ Microbiol 64:3791-3797
34. Burdige DJ, Nealson KH (1985) Microbial manganese reduction by enrichment cultures from coastal marine sediments. Appl Environ Microbiol 50:491-497

35. Fendorf SE, Sparks DL, Franz JA, Camaioni DM (1993) Electron paramagnetic resonance stopped-flow kinetic study of manganese sorptiondesorption on birnessite. Soil Sci Soc Am J 57:57-62

36. Yang DS, Wang MK (2002) Synthesis and characterization of birnessite by oxidizing pyrochroite in alkaline conditions. Clay Clay Miner 50:63-69

37. Fredrickson JK, Zachara JM, Kennedy DW, Dong H, Onstott TC, Hinman NW et al (1998) Biogenic iron mineralization accompanying the dissimilatory reduction of hydrous ferric oxide by a groundwater bacterium. Geochim Cosmochim Acta 62:3239-3257

38. Jaisi DP, Dong H, Liu C (2007) Influence of biogenic Fe(II) on the extent of microbial reduction of Fe(III) in clay minerals nontronite, illite, and chlorite. Geochim Cosmochim Acta 71:1145-1158

39. Liu C, Zachara JM, Foster NS, Strickland J (2007) Kinetics of reductive dissolution of hematite by bioreduced anthraquinone-2,6-disulfonate. Environ Sci Technol 41:7730-7735

40. Burgos WD, Fang Y, Royer RA, Yeh GT, Dempsey BA (2003) Reaction-based modeling of quinone-mediated bacterial iron(III) reduction. Geochim Cosmochim Acta 67:2735-2748

41. Brose DA, James BR (2010) Oxidation-reduction transformations of chromium in aerobic soils and the role of electron-shuttling quinones. Environ Sci Technol 44:9438-9444

42. Briker $\mathrm{O}$ (1965) Some stability relations in the system $\mathrm{Mn}-\mathrm{O}_{2}-\mathrm{H}_{2} \mathrm{O}$ at $25^{\circ} \mathrm{C}$ and one atmosphere total pressure. Am Mineral 50:1296-1354

43. Clark WM (1960) Oxidation-reduction potential of organic systems. The Williams and Wilkins Co, Baltimore

44. Villalobos M, Toner B, Bargar J, Sposito G (2003) Characterization of the manganese oxide produced by Pseudomonas putida strain MnB1. Geochim Cosmochim Acta 67:2649-2662

45. Webb SM, Tebo BM, Bargar JR (2005) Structural characterization of biogenic $\mathrm{Mn}$ oxides produced in seawater by the marine bacillus sp. strain SG-1. Am Mineral 90:1342-1357

\section{Publish with ChemistryCentral and every scientist can read your work free of charge \\ "Open access provides opportunities to our colleagues in other parts of the globe, by allowing anyone to view the content free of charge."}

W. Jeffery Hurst, The Hershey Company.

- available free of charge to the entire scientific community

- peer reviewed and published immediately upon acceptance

- cited in PubMed and archived on PubMed Central

- yours - you keep the copyright

Submit your manuscript here:

http://www.chemistrycentral.com/manuscript/ 